\title{
Perkembangan Sel T Regulator Periferal dan Mekanisme Supresi in vitro
}

\author{
Muhaimin Rifa'i* \\ Jurusan Biologi, Fakultas Matematika dan Ilmu Pengetahuan Alam, Universitas Brawijaya, Malang
}

\begin{abstract}
Abstrak
Sel T regulator yang ditandai dengan $\mathrm{CD}^{+} \mathrm{CD}^{+} 5^{+}$Foxp $^{3}$ memegang peranan kunci pada sistem toleran tubuh. Sel T regulator ini diperlukan untuk mengendalikan sel efektor yang teraktivasi. Sel T regulator melakukan fungsinya sebagai pengendali sel efektor dan pembentuk sistem toleran dengan cara tidak hanya sebagai supresor namun juga pengatur sistem homeostasis. Sel T regulator mempunyai daya kendali terhadap sel lain yang terlibat pada sistem imun. Kemampuan mengendalikan sel lain ini mutlak diperlukan untuk menghindari terjadinya penyakit autoimun dan penolakan transplantasi. Kerja sel T regulator mempengaruhi respon imun terhadap alergen namun melemahkan sel efektor melawan sel tumor dan patogen. Di samping itu pada beberapa kasus diketahui bahwa sel T regulator juga menyebabkan sel efektor kehilangan fungsinya. Sampai sekarang mekanisme kerja sel T regulator secara seluler dan molekuler belum sepenuhnya diketahui, namun ada bukti tentang pentingnya sel ini dari banyak aspek biologi. Pengetahuan tentang adanya strategi mengaktifkan dan menginduksi munculnya sel T regulator dari sel T konvensional membuka kemungkinan untuk melakukan rerkayasa in vivo sebagai langkah imunoterapi khususnya pada model penyakit autoimun. Bahasan saat ini merangkum pengetahuan tentang sel T regulator sebagai imunoterapi dan harapan dimasa depan terhadap pemanfaatan sel ini.
\end{abstract}

Kata kunci: autoimun, $\mathrm{CD} 4^{+} \mathrm{CD} 25^{+} \mathrm{Foxp}^{+}$, sel efektor, Sel T regulator

\section{PENDAHULUAN}

Terjadinya toleransi terhadap self antigen ketika sistem imun melakukan tugasnya merupakan persyaratan mutlak yang harus dipenuhi agar tidak terjadi kerusakan pada setiap individu yang sehat. Proses pembentukan reseptor sel T ( $T$ Cell Receptor atau TCR) dengan genetic rearrangement memungkinkan terjadinya resiko yaitu terjadinya sel yang lolos sehingga terdapat sel T yang bersifat autoreaktif. Mekanisme terbentuknya toleransi berdasarkan penghapusan klon sel $\mathrm{T}$ yang bersifat reaktif pada organ timus diketahui merupakan mekanisme yang paling mungkin untuk mencegah terjadinya autoagresif pada peripheral, sehingga timus dikenal sebagai pusat toleran segaligus sebagai organ limfoid primer [1]. Namun, karena penghapusan klonal dalam timus tidak sempurna, sel T autoreaktif dapat lolos dari seleksi dan bersirkulasi pada individu yang sehat [2]. Diduga ada mekanisme yang mengontrol secara ketat sel-sel autoreaktif yang lolos dari seleksi negatif $[3,4,5$, $6,7]$. Banyak peneliti yang berhasil menunjukkan potensi besar sel spesifik yang mempunyai peran

\footnotetext{
* Alamat korespondensi penulis:

Muhaimin Rifa'i

e-mail : rifa123@ub.ac.id

Alamat : Jurusan Biologi, Fakultas Matematika dan Ilmu Pengetahuan Alam, Universitas Brawijaya,

Jl. Veteran, Malang, 65145
}

sebagai pengatur dan mencegah terjadinya respon imun pada self-antigen. Sel tersebut selanjutnya dikenal sebagai sel T regulator. Sel T regulator mencegah terjadinya penyakit autoimun akibat sel T autoreaktif [3], melindungi terjadinya penolakan pada transplantasi [8], mencegah terjadinya reaksi GVHD [9] dan mencegah terjadinya reaksi alergi [10]. Defisiensi sel $T$ regulator banyak berkaitan dengan timbulnya penyakit multiple sclerosis, diabetes tipe-1, rheumatoid arthritis dan kejadian alergi $[11,12,13]$. Namun, peningkatan jumlah sel T regulator mengakibatkan lumpuhnya sel-sel efektor pada pasien kanker dan infeksi mikroba $[14,15]$. Usaha menyeimbangkan sistem kontrol agar tubuh tetap terjaga dari infeksi namun juga bebas dari penyakit autoimun merupakan usaha yang dilakukan oleh kalangan ilmuwan pada bidang imunologi dalam konsep imunoterapi terhadap penyakit kanker, autoimun, infeksi, dan trans-plantasi.

Sel $\mathrm{T}$ regulator telah diketahui mempunyai asal-usul yang berbeda. Secara garis besar sel T regulator dibedakan menjadi dua jenis yakni sel T regulator natural (profesional) dan sel T regulator hasil induksi. Sel $T$ regulator natural (profesional) merupakan populasi sel T yang mengekspresikan molekul CD25. Molekul CD25 adalah rantai alfa dari reseptor IL-2. Sel T regulator natural ditandai dengan $\mathrm{CD}^{+}{ }^{+} \mathrm{CD} 25^{+}$(nT reg). Sel ini muncul dan mengalami pemasakan pada organ timus saat 
perkembangan awal suatu individu [16]. Pada mencit yang dilakukan thymectomy sejak awal kelahiran akan mengalami defisiensi sel $T$ regulator sehingga mencit tersebut akan menderita berbagai penyakit autoimun yang ditandai dengan kerusakan jaringan akibat reaksi sel $T$ auto-regresif [17] dan hilangnya homeostasis yang ditandai dengan terjadinya sel $T$ autoreaktif [18]. Sel T regulator natural ini berkembang di timus dan mempunyai karakteristik yang sangat berbeda dengan sel T konvensional yang lain [19]. Sel $T$ regulator mengisi sekitar 4-10\% sel T populasi CD4 periferal

[4]. Sel $T$ regulator mempunyai beberapa penanda pada permukan sel atau intra sel. Penanda tersebut meliputi ekspresi positif CD25, CTLA-4, GITR, OX40, dan L-selektin (CD62L), sehingga memungkinkan isolasi $\mathrm{n} T$ reg untuk menunjukkan perannya in vitro [6] dan in vivo

[5]. Namun demikian, sampai saat ini masih terjadi banyak kontroversi dari para ilmuwan pada bidang imunologi, sehingga pentingnya molekul permukaan yang berupa rantai alfa reseptor IL-2 tetap saja belum terjelaskan secara lengkap [20, 21]. Sampai saat ini ada satu keyakinan bahwa molekul intra-nukleus, Foxp3 merupakan penanda terpenting dari sel $T$ regulator. Foxp3 merupakan faktor transkripsi yang keberadaannya mutlak diperlukan agar suatu individu hidup normal. Bukti ini diperoleh dari penelitian menggunakan mencit knockout (knockout mice). Penghapusan gen Foxp3 pada mencit menyebabkan mencit akan kehilangan sel $\mathrm{T}$ regulator. Meskipun pada mencit Foxp3knockout ekspresi CD25 nampak normal, namun sel-sel yang mengeksprsikan molekul tersebut tidak menunjukkan sebagai sel regulator maupun supresor. Pada mencit Foxp3-knockout akan terjadi penyakit autoimun yang parah, lymphoproliferative fatal, yang menyebabkan kematian mencit tersebut pada umur sekitar 4-5 minggu setelah kelahiran [22]. Pada manusia mutasi gen Foxp3 dapat menyebabkan penyakit IPEX (Immunodysregu-ation, Polyendocrinopathy, Enteropati, sindrom X-linked). Penyakit ini tergolong langka dan muncul fenotipnya sejak anak-anak yang dicirikan oleh autoimun yang parah [23]. Analisis terhadap pasien IPEX disimpulkan bahwa hilangnya Foxp3 menyebabkan cacatnya sel $\mathrm{T}$ regulator dan hilangnya aktivitas supresi terhadap sel-sel efektor. Hal yang sangat menarik bahwa mencit yang mengalami autoimun bisa diselamatkan dengan mentransfer sel T regulator $\mathrm{CD}^{+}{ }^{+} \mathrm{CD} 25^{+}$Foxp $^{+}$ [24]. Pada mencit, Foxp3 secara eksklusif hanya diekspresikan pada sel T regulator [20]. Informasi ini jelas menunjukkan bahwa pada mencit gen Foxp3 penting bagi perkembangan dan fungsi sel T regulator. Temuan Foxp3 ini memberikan peran yang besar dalam mengidentifikasi sel $T$ regulator. Molekul CD25 dan GITR meskipun menjadi penanda sel $T$ regulator namun tidak bersifat mutlak karena molekul tersebut juga diekspresikan oleh sel-sel yang teraktivasi. Penelitian lebih lanjut mengenai Foxp3 pada sel T manusia, menunjukkan adanya perbedaan yang besar dibandingkan dengan mencit, sehingga beberapa mekanisme yang terjadi pada mencit belum tertu sama dengan manusia. Berbeda dengan yang ada pada mencit, Foxp3 pada manusia juga mengalami pening-katan setelah sel T CD4 konvensional distimuli melalui jalur TCR, hal ini menunjukkan bahwa sel T regulator pada manusia lebih mudah diinduksi daripada yang ada pada mencit $[25,26]$.

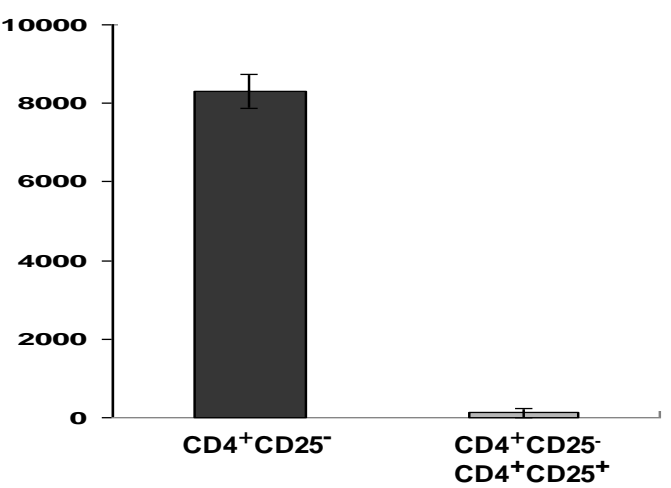

Gambar 1. Sel T regulator dapat menghambat proliferasi sel target atau responder in vitro. Sel T konvensional $\mathrm{CD} 4^{+} \mathrm{CD} 25^{-}$dari mencit diisolasi dan dikultur terpisah atau dicampur dengan sel $\mathrm{T}$ regulator. Kultur dilakukan pada 96-well plate dengan adanya APC yang berasal dari sel spleen yang diradiasi dosis letal. Kultur ditambah anti-CD3 untuk menstimulasi dan mengaktivasi sel dalam kultur. Analisis dilakukan tiga hari setelah kultur dengan menggunakan deteksi thymidine.

\section{MEKANISME KERJA $T$ reg IN VITRO DAN PEMBENTUKAN $T$ reg}

Sejauh ini diyakini bahwa kerja sel T regulator terjadi melalui mekanisme kontak antar sel. Kontak antar sel ini memberikan sinyal yang dapat mengaktifkan sel $T$ reg melalui jalur TCR ( $T$ cell receptor). Semua penelitian yang menggunakan hewan dan manusia sebagai bahan percobaan telah melaporkan bahwa meknisme kerja sel $T$ reg memerlukan kontak antara sel $T$ reg dengan sel responder. Sel responder yang dikultur tanpa kehadiran $T$ reg akan berproliferasi 
sangat cepat, namun dengan adanya $T$ reg proliferasi dapat dihentikan secara sempurna (Gambar 1). Para ilmuwan menduga kontak antar sel yang menimbulkan sinyal melalui TCR akan mempengaruhi sel $T$ reg mengekspresikan molekul pada permukaannya yang digunakan untuk melakukan supressor. Namun, meskipun para ilmuwan berusaha dengan untuk mengetahui molekul yang terkspresi pada permukaan sel, sejauh ini masih belum diketahui jawabannya. Sementara ini diyakini $T$ reg menghambat aktivasi dan proliferasi sel responder dengan menekan sintesis IL-2 sel [26]. Sel $\mathrm{T}$ regulator diyakini mempunyai asal yang berbeda-beda. Salah satu sel T regulator yang disebut sebagai "natural atau profesional" diketahui terbentuk di dalam organ timus dan mempunyi molekul yang ditandai dengan $\mathrm{CD}^{+}{ }^{+} \mathrm{CD} 25^{+}$Foxp $^{+}$. CD25 merupakan rantai $\alpha$ dari reseptor IL-2 [16]. Thymectomy yang dilakukan pada mencit yang berumur kurang dari tiga hari akan kehilangan $T$ reg pada darah maupun organ limfoid periferal. Ketiadaan sel $T$ reg ini akan mengakibatkan munculnya penyakit autoimun yang ditandai dengan kerusakan auto aggressive [17]. Hilangnya sel $T$ reg dari sirkulasi juga menimbulkan hilangnya homeostasis dan rusaknya mekanisme kekebalan [18]. Sel T regulator yang dibentuk oleh timus ini mempunyai karakter yang sangat berbeda dengan sel konvensional yang umumnya mempunyai TCR dengan sifat autoreaktif [19]. Sel $T$ regulator mempunyai proporsi $5-10 \%$ pada populasi CD4 yang berada pada sirkulasi darah maupun yang homing pada organ limfoid sekunder. Secara morfologi sel T regulator tidak menunjukkan perbedaan yang besar dibanding sel $T$ konvensional yang lain, namun secara umum sel $T$ reg mempunyai ukuran sedikit lebih kecil dari sel limfosit lainnya. Foxp3 mempunyai peran sebagai faktor perkembangan sel $T$ regulator dan sekaligus mengendalikan fungsinya $[20,21]$. Mencit yang dihapus gen Foxp3-nya akan mengalami autoimun yang parah meskipun ekspresi molekul CD25 dalam keadaan normal. Mencit Foxp3 $3^{-/-}$akan mati pada umur 4-5 minggu setelah kelahiran oleh adanya autoimun yang sangat parah yang ditandai dengan hilangnya homeostasis dan terjadi proliferasi sel-sel limfosit yang melebihi keadaan normal [22].

PEMBENTUKANSEL T REGULATOR DAN MEKANISME KERJANYA

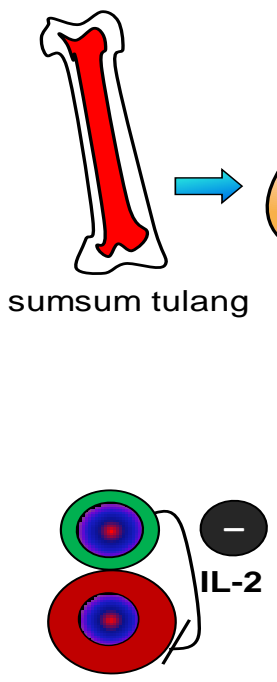

a)

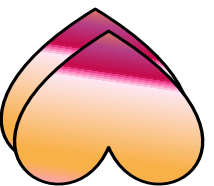

timus

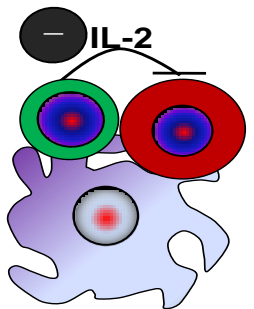

b)

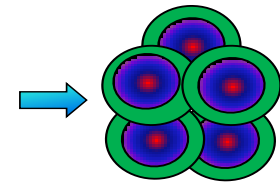

sel $\mathrm{T}$ regulator periferal
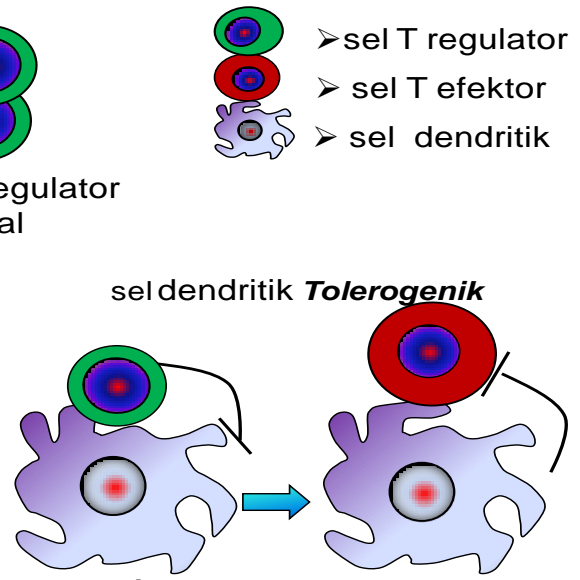

c)

Gambar 2. Pembentukan dan Mekanisme Kerja Sel T Regulator

Keterangan:

Sel T regulator dapat terbentuk dengan berbagai cara. $T$ reg dapat terbentuk dari perkembangan sel T pada organ timus. $T$ reg yang berkembang pada timus dikenal dengan nama "professional regulatory $T$ cell" atau "natural accuring regulatory $T$ cell", sedangkan yang terbentuk di daerah periferal disebut induced regulatory $T$ cells. a) $T$ reg mempunyai potensi melakukan supresi terhadap sel efektor. Salah satu mekanisme supresi adalah mencegah produksi IL-2 disamping menghambat proliferasi sel target atau responder. $T$ reg dapat secara langsung melakukan regulasi melalui kontak antar sel tanpa intervensi APC. b) $T$ reg mencegah sekresi IL-2 oleh efektor dengan intervensi sel dendritik. c) Sel dendritik yang telah berinteraksi dengan $T$ reg mempunyai daya supresi terhadap sel efektor sehingga disebut sel dendritik "tolerogenik". 
Cacat genetik yang terkait dengan Foxp3 adalah IPEX (immunodysregulation, polyendocrinopathy, Enteropati, sindrom X-linked) merupakan penyakit langka pada manusia. IPEX terpaut oleh kromosom $X(X$-linked $)$. Cacat genetik IPEX ada anak-anak, dicirikan oleh penyakit autoimun yang disebabkan oleh mutasi gen Foxp3 [23]. Analisis yang sangat teliti pada pasien IPEX dan mencit knockout gen Foxp3 menunjukkan bukti kurangnya sel T regulator dari dua model tersebut. Kurangnya sel $\mathrm{T}$ regulator mengakibatkan hilangnya daya penekanan (suppression) terhadap sel-sel autireaktif. Mencit Foxp3 $^{-/-}$dapat disembuhkan dengan mentransfer sel $\mathrm{T}$ regulator $\mathrm{CD}^{+}{ }^{+} \mathrm{CD} 25^{+}{ }^{+}$oxp $3^{+}$yang berasal dari mencit normal $[24,25,26]$. Secara eksklusif, Foxp3 pada mencit dipresentasikan oleh sel $\mathrm{T}$ $\mathrm{CD} 4{ }^{+} \mathrm{CD} 25^{+}$dan mempunyai daya tekan terhadap sel $\mathrm{T}$ konvensional $\mathrm{CD} 4^{+} \mathrm{CD} 25^{-}$. Pada mencit, Foxp3 penting untuk perkembangan sel $T$ regulator sekaligus menentukan adanya fungsi sebagai sel represor [20]. Temuan Foxp3 ini membedakan sel $T$ regulator dari sel $T$ konvensional, karena penanda lain berupa molekul CD25 maupun GITR tidak hanya diekspresikan oleh sel $\mathrm{T}$ regulator namun juga sel lain yang mengalami aktivasi. Dari data penelitian sekarang telah diketahui bahwa ekspresi Foxp3 pada mencit berbeda dibandingkan dengan yang ada pada manusia. Foxp3 pada mencit tidak dapat diinduksi oleh aktivasi melalui TCR, tetapi pada manusia Foxp3 dapat diinduksi oleh aktivasi TCR. Penemuan ini menjadi informasi penting sebagai strategi untuk memperoleh sel $T$ regulator in vitro [25]. Perkembangan dan mekanisme kerja sel $\mathrm{T}$ reg pada manusia dapat dilihat pada Gambar 2.

\section{DAFTAR PUSTAKA}

1. Chai, J.G., S.A. Xue, D. Coe, C. Addey, I. Bartok, D. Scott, E. Simpson, H.J. Stauss, S. Hori, S. Sakaguchi, J. Dyson. 2005. Regulatory T cells, derived from naive $\mathrm{CD} 4{ }^{+} \mathrm{CD} 25^{-} \mathrm{T}$ cells by in vitro Foxp3 gene transfer, can induce transplantation tolerance. Transplantation. 79:1310-1316.

2. Akbari, O, P. Stock, R.H. DeKruyff, D.T. Umetsu. 2003. Role of regulatory T cells in allergy and asthma. Curr Opin Immunol. 15:627-633.

3. Viglietta, V, C. Baecher-Allan, H.L. Weiner, D.A. Hafler. 2004. Loss of functional suppression by $\mathrm{CD} 4{ }^{+} \mathrm{CD} 25^{+}$regulatory $\mathrm{T}$ cells in patients with multiple sclerosis. J Exp Med. 199:971-979.

4. Lindley, S, C.M. Dayan, A. Bishop, B.O. Roep,
M. Peakman, T.I. Tree. 2005. Defective suppressor function in $\mathrm{CD}^{+} \mathrm{CD} 25^{+}$T-cells from patients with type 1 diabetes. Diabetes. 54:92-99.

5. Ehrenstein, M.R., J.G. Evans, A. Singh, S. Moore, G. Warnes, D.A. Isenberg, C. Mauri. 2004. Compromised function of regulatory $T$ cells in rheumatoid arthritis and reversal by anti-TNF alpha therapy. J Exp Med. 200:277285.

6. Curiel, T.J., G. Coukos, L. Zou, X. Alvarez, P. Cheng, P. Mottram, M. Evdemon-Hogan, J.R. Conejo-Garcia, L. Zhang, M. Burow, Y. Zhu, S. Wei, I. Kryczek, B. Daniel, A. Gordon, L. Myers, A. Lackner, M.L. Disis, K.L. Knutson, L. Chen, W. Zou. 2004. Specific recruitment of regulatory $T$ cells in ovarian carcinoma fosters immune privilege and predicts reduced survival. Nat Med. 10:942-949.

7. Endharti, A.T., M. Rifa'I, Z. Shi, Y. Fukuoka, Nakahara, Y. Kawamoto, K. Takeda, K. Isobe, H. Suzuki. 2005. Cutting edge: CD8+CD122+ regulatory $\mathrm{T}$ cells produce $\mathrm{IL}-10$ to suppress IFN-gamma production and proliferation of CD8+ $\mathrm{T}$ cells. Journal of immunology, 175 (11):7093-7097.

8. Itoh, M., T. Takahashi, N. Sakaguchi, Y. Kuniyasu, J. Shimizu, F. Otsuka, S. Sakaguchi. 1999. Thymus and autoimmunity: production of $\mathrm{CD}_{25}{ }^{+} \mathrm{CD} 4^{+}$naturally anergic and suppressive $T$ cells as a key function of the thymus in maintaining immunologic selftolerance. J Immunol. 162: 5317-5326.

9. Hsieh, C.S, Y. Liang, A.J. Tyznik, S.G. Self, D. Liggitt, A.Y. Rudensky. 2004. Recognition of the peripheral self by naturally arising $\mathrm{CD} 25^{+}$ $\mathrm{CD}^{+}{ }^{+} \mathrm{T}$ cell receptors. Immunity. 21: 267-277.

10. Hori, S., T. Nomura, S. Sakaguchi. 2003. Kontrol of regulatory $\mathrm{T}$ cell development by the transcription factor Foxp3. Science. 299: 1057-1061.

11. Fontenot, J.D., M.A. Gavin, A.Y. Rudensky, 2003. Foxp3 programs the development and function of $\mathrm{CD}^{+}{ }^{+} \mathrm{CD} 25^{+}$regulatory T cells. Nat Immunol. 4: 330-336.

12. Brunkow, M.E., E.W. Jeffery, K.A. Hjerrild, B. Paeper, L.B. Clark, S.A. Yasayko, J.E. Wilkinson, D. Galas, S.F. Ziegler, F. Ramsdell. 2001. Disruption of a new forkhead/wingedhelix protein, scurfin, results in the fatal lymphoproliferative disorder of the scurfy mouse. Nat Genet. 27:68-73.

13. Wildin, R.S, F. Ramsdell, J. Peake, F. Faravelli, J.L. Casanova, N. Buist, E. Levy-Lahad, M. Mazzella, O. Goulet, L. Perroni, F.D. Bricarelli, G. Byrne, M. McEuen, S. Proll, M. Appleby, M.E. Brunkow. 2001. X-linked 
neonatal diabetes mellitus, enteropathy and endo-crinopathy syndrome is the human equivalent of mouse scurfy. Nat Genet. 27: 18-20.

14. Nishimura, E, T. Sakihama, R. Setoguchi, K. Tanaka, S. Sakaguchi. 2004. Induction of antigen-specific immunologic tolerance by in vivo and in vitro antigen-specific expansion of naturally arising Foxp $3^{+} \mathrm{CD} 25^{+} \mathrm{CD} 4^{+}$regulatory T cells. Int Immunol. 16: 1189-1201.

15. Ziegler, S.F. 2005. FOXP3: of mice and men. Annu Rev Immunol. 25:342-349.

16. Shevach, E.M., R.S. McHugh, C.A. Piccirillo, A.M. Thornton. 2001. Kontrol of T-cell activation by $\mathrm{CD}^{+} \mathrm{CD} 25^{+}$suppressor $\mathrm{T}$ cells. Immunol Rev. 182:58-67.

17. Takahashi, T., T. Tagami, S. Yamazaki, T. Uede, Shimizu, N. Sakaguchi, T.W. Mak, S. Sakaguchi. 2000. Immunologic self-tolerance maintained by $\mathrm{CD} 25(+) \mathrm{CD} 4(+)$ regulatory $\mathrm{T}$ cells constitutively expressing cytotoxic $T$ lympho-cyte-associated antigen 4. J Exp Med. 192:303-310.

18. Zhao, D.M., A.M. Thornton, R.J. Dipaolo, E.M. Shevach. 2006. Activated $\mathrm{CD} 4^{+} \mathrm{CD} 25^{+} \mathrm{T}$ cells selectively kill B lymphocytes. Blood. 33:675680.

19. Gondek, D.C., L.F. Lu, S.A. Quezada, S. Sakaguchi, R.J. Noelle. 2005. Cutting edge: contact-mediated suppression by CD4+CD25+ regulatory cells involves a granzyme Bdependent, perforin-independent mechanism. J Immunol. 174:1783-1786.

20. Kretschmer, K., I. Apostolou, D. Hawiger, K. Khazaie, M.C. Nussenzweig, H. von Boehmer. 2005. Inducing and expanding regulatory $T$ cell populations by foreign antigen. Nat Immunol. 6:1219-1227.

21. Stassen, M, S. Fondel, T. Bopp, C. Richter, C. Muller, J. Kubach, C. Becker, J. Knop, A.H. Enk, S. Schmitt, E. Schmitt, H. Jonuleit. 2004. Human $\mathrm{CD} 25^{+}$regulatory $\mathrm{T}$ cells: two subsets defined by the integrins alpha 4 beta 7 or alpha 4 beta 1 confer distinct suppressive properties upon $\mathrm{CD}^{+}{ }^{+} \mathrm{T}$ helper cells. Eur $\mathrm{J}$ Immunol. 34:1303-1311.

22. Rifa'i, M., Y. Kawamoto, I. Nakashima, H. Suzuki. 2004. Essential Roles of $\mathrm{CD} 8^{+} \mathrm{CD} 122^{+}$ Regulatory T cells in the Maintenance of T Cell Homeostasis. J Exp Med. 200. 9:1123-1134.

23. Rifa'i, M., Z. Shi, Y. Lee, H. Shiku, K. Isobe, H. Suzuki. 2008. $\mathrm{CD}^{+} \mathrm{CD} 122^{+}$regulatory T cells recognize activated $T$ cells via conventional MHC class I- $\alpha \beta$ TCR interaction and become IL-10 producing active regulatory cells. J
International Imunologi. 20. 7:937-947.

24. Rifa'i, M., Z. Shi, K. Isobe, H. Suzuki. 2007. Essential role of $\mathrm{CD} 8^{+} \mathrm{CD} 122^{+}$regulatory $\mathrm{T}$ cells in the recovery from experimental autoimmune encephalomyelitis. Journal of immunology (Baltimore,Md.:1950) 2008. 180. 2:825-32.

25. Shi, Z., M. Rifa'i, Y. Lee, K. Isobe, H. Suzuki. 2007. Importance of CD80/CD86-CD28 interaction in the recognation of target cells by $\mathrm{CD}^{+}{ }^{+} \mathrm{CD} 122^{+}$regulatory $\mathrm{T}$ cells. Journal Immunology. 2008. 124. 1:121-128.

26. Shi, Z., Y. Okuno, M. Rifa'i, A.T. Endharti, K. Akane, K. Isobe, $H$. Suzuki. Human $\mathrm{CD}^{+}{ }^{+} \mathrm{CXCR}^{+}{ }^{+} \mathrm{T}$ cells have the same function as murine $\mathrm{CD}^{+}{ }^{+} \mathrm{CD} 122^{+}$T reg Eur. J. Immunol. 39. 08:2106-2119. 